\title{
Unprecedented Chemical Transformation of Semicarbazones Mediated by Wilkinson's Catalyst
}

\author{
Indrani Pal, ${ }^{\text {aa }}$ Swati Dutta, ${ }^{\text {aa }}$ Falguni Basuli, ${ }^{\text {aa }}$ Savitha Goverdhan, ${ }^{1 \mathrm{~b}}$ Shie-Ming Peng, ${ }^{1 \mathrm{c}}$ \\ Gene-Hsiang Lee, ${ }^{1 \mathrm{c}}$ and Samaresh Bhattacharya ${ }^{*}, 1 \mathrm{a}$ \\ Department of Chemistry, Inorganic Chemistry Section, Jadavpur University, \\ Kolkata 700 032, India, Department of Inorganic Chemistry, Indian Institute of Technology, \\ Kanpur 208016, India, and Department of Chemistry, National Taiwan University, \\ Taipei, Taiwan, ROC
}

Received March 7, 2003

\begin{abstract}
para-Nitrobenzaldehyde semicarbazone undergoes an unusual chemical transformation upon reaction with $\left[\mathrm{Rh}\left(\mathrm{PPh}_{3}\right)_{3} \mathrm{Cl}\right]$ in the presence of trialkyl and dialkylamines $\left(\mathrm{NR}_{2} \mathrm{R}^{\prime} ; \mathrm{R}=\mathrm{Et}\right.$, ${ }^{\mathrm{P} P}$, ${ }^{\mathrm{n}} \mathrm{Bu} ; \mathrm{R}^{\prime}=\mathrm{H}$ or $\left.\mathrm{R}^{\prime}=\mathrm{R}\right)$ via dissociation of the $\mathrm{C}-\mathrm{NH}_{2}$ bond and formation of a new $\mathrm{C}-\mathrm{NR}_{2}$ bond (where the $\mathrm{NR}_{2}$ fragment is provided by the amine). The transformed semicarbazone ligand binds to rhodium as a dianionic $\mathrm{C}, \mathrm{N}, \mathrm{O}$-donor to afford complexes of type $\left.\left[\mathrm{Rh}\left(\mathrm{PPh}_{3}\right)_{2}(\mathrm{CNO}-\mathrm{NR})_{2}\right) \mathrm{Cl}\right]\left(\mathrm{CNO}-\mathrm{NR}_{2}=\right.$ the coordinated semicarbazone ligand). Another group of semicarbazones (viz. salicylaldehyde semicarbazone, 2-hydroxyacetophenone semicarbazone, and 2-hydroxynaphthaldehyde semicarbazone) has also been observed to undergo a similar chemical transformation upon reaction with $\left[\mathrm{Rh}\left(\mathrm{PPh}_{3}\right)_{3} \mathrm{Cl}\right]$ under similar experimental conditions as before, and these transformed semicarbazones bind to rhodium as dianionic O,N,O-donors affording complexes of the type $\left[\mathrm{Rh}\left(\mathrm{PPh}_{3}\right)_{2}\left(\mathrm{ONO}^{n}-\mathrm{NR}{ }_{2}\right) \mathrm{Cl}\right]\left(\mathrm{ONO}^{n}-\mathrm{NR}_{2}=\right.$ the coordinated semicarbazone ligand; $n=1-3)$. The structure of the $\left[\mathrm{Rh}\left(\mathrm{PPh}_{3}\right)_{2}\left(\mathrm{CNO}-\mathrm{NEt}_{2}\right) \mathrm{Cl}\right]$ and $\left[\mathrm{Rh}\left(\mathrm{PPh}_{3}\right)_{2}\right.$ $\left(\mathrm{ONO}^{2}-\mathrm{NR}_{2}\right) \mathrm{Cl}$ ] complexes has been determined. All the complexes show characteristic ${ }^{1} \mathrm{H}$ NMR signals. They also show intense absorptions in the visible and ultraviolet region. Cyclic voltammetry on the complexes shows an oxidative response within $0.52-0.97 \mathrm{~V}$ versus SCE and a reductive response within -1.00 to $-1.27 \mathrm{~V}$ versus SCE, where both the responses are believed to be centered on the semicarbazone ligand.
\end{abstract}

\section{Introduction}

There has been considerable interest in the chemistry of transition metal complexes of the semicarbazone and thiosemicarbazone ligands, primarily because of their bioinorganic relevance ${ }^{2}$ and particularly because of their potentially beneficial biological (viz. antibacterial, antimalarial, antiviral, and antitumor) activities. ${ }^{3}$ However, we have been studying chemistry of the platinum metal complexes of the semicarbazone and thiosemicarbazone ligands with special reference to the variable coordination modes displayed by these

* To whom correspondence should be addressed. E-mail: samaresh_b@hotmail.com.

(1) (a) Jadavpur University. (b) Indian Institute of Technology. (c) National Taiwan University.

(2) (a) West, D. X.; Liberta, A. E.; Padhye, S. B.; Chikate, R. C.; Sonawane, P. B.; Kumbhar, A. S.; Yerande, R. G. Coord, Chem. Rev. 1993, 123, 49. (b) West, D. X.; Padhye, S. B.; Sonawane, P. B. Struct. Bonding 1992, 76, 1. (c) Haiduc, I.; Silvestru, C. Coord. Chem. Rev. 1990, 99, 253. (d) Padhye, S. B.; Kaffman, G. B. Coord. Chem. Rev. 1985, 63, 127. (e) Campbell, M. J. M. Coord. Chem. Rev. 1975, 15, 279.

4338 Inorganic Chemistry, Vol. 42, No. 14, 2003 ligands, ${ }^{4}$ and the present report has emerged from this continuous study. For this work, a group of five semicarbazones of para-substituted benzaldehydes (1) have been chosen as the principal ligand, and rhodium has been selected as the metal.
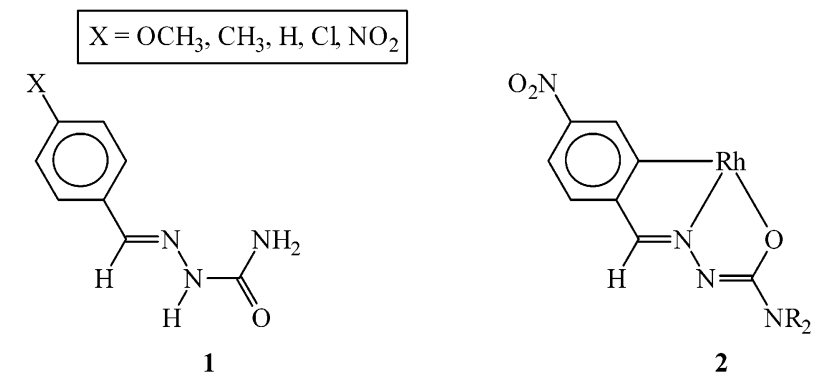

Our recent studies on the ruthenium complexes of these ligands have shown that they can bind to the metal as a bidentate N,O-donor and, depending on the experimental 
conditions, afford either four- or five-membered chelate rings. ${ }^{4 \mathrm{c}}$ The para-nitrobenzaldehyde semicarbazone $(\mathbf{1}, \mathrm{X}=$ $\mathrm{NO}_{2}$ ) can also coordinate to ruthenium as a tridentate $\mathrm{C}, \mathrm{N}, \mathrm{O}-$ donor affording organometallic complexes. ${ }^{4 c}$ Similar C,N,Otricoordination by such ligands was also observed by others. ${ }^{5}$ The facile formation of organometallic complexes by the benzaldehyde semicarbazones has encouraged us to explore the possibility of synthesizing organorhodium complexes of these ligands, and the Wilkinson's catalyst, viz. $\left[\mathrm{Rh}\left(\mathrm{PPh}_{3}\right)_{3^{-}}\right.$ $\mathrm{Cl}$, has been chosen as the rhodium starting material for this purpose because of its ability, as we have already experienced, to form organometallic complexes with $\mathrm{C}, \mathrm{N}, \mathrm{O}-$ donor ligands. ${ }^{6}$ Reaction of $\left[\mathrm{Rh}\left(\mathrm{PPh}_{3}\right)_{3} \mathrm{Cl}\right]$ has been carried out with all five benzaldehyde semicarbazones (1) in the presence of a base $\left(\mathrm{NR}_{2} \mathrm{R}^{\prime}, \mathrm{R}=\mathrm{Et},{ }^{\mathrm{i}} \mathrm{Pr},{ }^{\mathrm{n}} \mathrm{Bu} ; \mathrm{R}^{\prime}=\mathrm{R}, \mathrm{H}\right)$. However, only the reaction with para-nitrobenzaldehyde semicarbazone has afforded a family of interesting organorhodium complexes, ${ }^{7}$ where the semicarbazone ligand has been found to undergo an unusual chemical transformation via dissociation of the $\mathrm{C}-\mathrm{NH}_{2}$ bond and formation of a new $\mathrm{C}-\mathrm{NR}_{2}$ bond (where the $\mathrm{NR}_{2}$ fragment is provided by the base). The transformed ligand remains bound to rhodium(III) as a dianionic tridentate $\mathrm{C}, \mathrm{N}, \mathrm{O}-$-donor (2) affording organorhodium complexes of type $\left[\mathrm{Rh}\left(\mathrm{PPh}_{3}\right)_{2}\left(\mathrm{CNO}-\mathrm{NR}_{2}\right) \mathrm{Cl}\right]$ (where $\mathrm{CNO}-\mathrm{NR}_{2}$ refers to the coordinated ligand in 2).

In order to check the generality, if any, of the described

(3) (a) Jouad, E. M.; Thanh, X. D.; Bouet, G.; Bonneau, S.; Khan, M. A. Anticancer Res. 2002, 22, 1713. (b) Ferrari, M. B.; Bisceglie, F.; Pelosi, G.; Sassi, M.; Tarasconi, P.; Cornia, M.; Capacchi, S.; Albertini, R.; Pinelli, S. J. Inorg. Biochem. 2002, 90, 113. (c) Cowly, A. R. Dilworth, J. R.; Donnely, P. S.; Labisbal, E.; Sousa, A. J. Am. Chem. Soc. 2002, 124, 5270. (d) Maurer, R. I.; Blower, P. J.; Dilworth, J. R.; Reynolds, C. A.; Zheng, Y.; Mullen, G. E. D. J. Med. Chem. 2002 45, 1420. (e) Patole, J.; Dutta, S.; Padhye, S.; Sinn, E. Inorg. Chim. Acta 2001, 318, 207. (f) Iakovidou, Z.; Papageorgiou, A.; Demertzis, M. A.; Mioglou, E.; Mourelatos, D.; Kotsis, A.; Yadav, P. N.; KovalaDemertzi, D. Anti-Cancer Drugs. 2001, 12, 65. (g) Kovala-Demertzi, D.; Miller, J. R.; Kourkoumelis, N.; Hadjikakou, S. K.; Demertzis, M. A. Polyhedron 1999, 18, 1005. (h) Miller, M. C., III; Stineman, C. N.; Vance, J. R.; West, D. X.; Hall, I. H. Anticancer Res. 1998 , 18, 4131. (i) Papageorgiou, A.; Iakovidou, Z.; Mourelatos, D.; Mioglou, E.; Boutis, L.; Kotsis, A.; Kovala-Demertzi, D.; Domopoulou, D. X.; Demertzis, M. A. Anticancer Res. 1997, 17, 247. (j) Dimmock, J. R.; Puthucode, R. N.; Smith, J. M.; Hetherington, M.; Quail, J. W.; Pugazhenthi, U.; Lechler, J.; Stables, J. P. J. Med. Chem. 1996, 39, 3984. (k) Kovala-Demertzi, D.; Domopoulou, A.; Demertzis, M. A.; Raptopoulou, C. P.; Terzis, A. Polyhedron 1994, 13, 1917. (1) Liberta, A. E.; West, D. X. Biometals 1992, 5, 121. (m) Kraker, A.; Krezoski, S.; Schneider, J.; Mingel, D.; Petering, D. H. J. Biol. Chem 1985, 260, 13710. (n) Scovill, J. P.; Klayman, D. L.; Franchino, C. F J. Med. Chem. 1982, 25, 1261. (o) Agrawal, K. C.; Sartorelli, A. C. Prog. Med. Chem. 1978, 15, 321. (p) Sartorellic, A. C.; Agrawal, K. C.; Tsiftsoglou, A. S.; Moore, A. C. Adv. Enzyme Regul. 1977, 15 117. (q) French, F. A.; Blanz, E., Jr. J. Med. Chem. 1970, 13, 1117

(4) (a) Gupta, P.; Basuli, F.; Peng, S. M.; Lee, G. H.; Bhattacharya, S. Inorg, Chem. 2003, 42, 2069. (b) Dutta, S.; Basuli, F.; Peng, S. M.; Lee, G. H.; Bhattacharya, S. New. J. Chem. 2002, 26, 1607. (c) Basuli, F.; Peng, S. M.; Bhattacharya, S. Inorg. Chem. 2001, 40, 1126. (d) Pal, I.; Basuli, F.; Mak, T. C. W.; Bhattacharya, S. Angew. Chem., Int. Ed. 2001, 40, 2923. (e) Basuli, F.; Peng, S. M.; Bhattacharya, S. Inorg. Chem. 2000, 39, 1120. (f) Basuli, F.; Ruf, M.; Pierpont, C. G.; Bhattacharya, S. Inorg. Chem. 1998, 39, 6113. (g) Basuli, F.; Peng, S. M.; Bhattacharya, S. Inorg. Chem. 1997, 36, 5645.

(5) Villa, J. M.; Pereira, M. T.; Ortiguiera, J. M.; Lopez-Torres, M.; Castineiras, A.; Fernandez, J. J.; Fernandez, A.; Lata, D. J. Organomet. Chem. 1998, 556, 21.

(6) Dutta, S.; Peng, S. M.; Bhattacharya, S. J. Chem. Soc., Dalton Trans. 2000, 4623.

(7) Ligands containing other substituents $\left(1, \mathrm{X} \neq \mathrm{NO}_{2}\right)$ afforded a dirty looking unidentifiable material. transformation, a second group of three potentially tridentate semicarbazones (3; viz. salicylaldehyde semicarbazone, 2-hydroxyacetophenone semicarbazone, and 2-hydroxynaphthaldehyde semicarbazone) have been allowed to react with $\left[\mathrm{Rh}\left(\mathrm{PPh}_{3}\right)_{3} \mathrm{Cl}\right]$ under similar experimental conditions. These new semicarbazones have also been observed to undergo similar chemical transformation as before and bind to rhodium(III) as a dianionic tridentate $\mathrm{O}, \mathrm{N}, \mathrm{O}$-donor (4) affording complexes of type $\left[\mathrm{Rh}\left(\mathrm{PPh}_{3}\right)_{2}\left(\mathrm{ONO}^{n}-\mathrm{NR}_{2}\right) \mathrm{Cl}\right]$ (where $\mathrm{ONO}^{n}-\mathrm{NR}_{2}$ stands for the coordinated ligand in 4). The
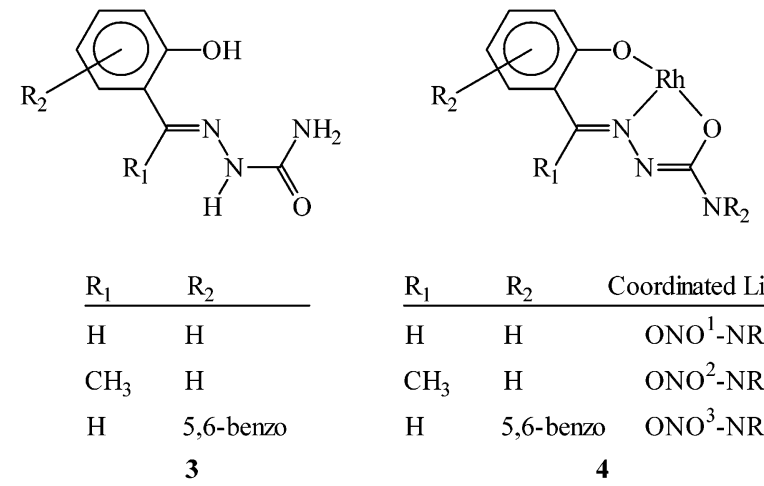

\begin{tabular}{llc}
$\mathrm{R}_{1}$ & $\mathrm{R}_{2}$ & Coordinated Ligand \\
\hline $\mathrm{H}$ & $\mathrm{H}$ & $\mathrm{ONO}^{1}-\mathrm{NR}_{2}$ \\
$\mathrm{CH}_{3}$ & $\mathrm{H}$ & $\mathrm{ONO}^{2}-\mathrm{NR}_{2}$ \\
$\mathrm{H}$ & 5,6-benzo & $\mathrm{ONO}^{3}-\mathrm{NR}_{2}$ \\
& & 4
\end{tabular}

chemistry of the $\left[\mathrm{Rh}\left(\mathrm{PPh}_{3}\right)_{2}\left(\mathrm{CNO}-\mathrm{NR}_{2}\right) \mathrm{Cl}\right]$ and $\left[\mathrm{Rh}\left(\mathrm{PPh}_{3}\right)_{2^{-}}\right.$ $\left.\left(\mathrm{ONO}^{n}-\mathrm{NR}_{2}\right) \mathrm{Cl}\right]$ complexes is reported in this paper with special reference to their formation, structure, and electrochemical properties.

\section{Experimental Section}

Materials. Rhodium trichloride was obtained from Arora Matthey, Kolkata, India. Triethylamine, diethylamine, tri- $n$-butylamine, and diisopropylamine were purchased from Aldrich. All other chemicals and solvents were reagent grade commercial materials and were used as received. [ $\left.\mathrm{Rh}\left(\mathrm{PPh}_{3}\right)_{3} \mathrm{Cl}\right]$ was synthesized by following a reported procedure. ${ }^{8}$ The semicarbazone ligands were prepared by reacting equimolar amounts of semicarbazide hydrochloride, sodium acetate, and the respective aldehyde or ketone in 1:1 ethanol-water mixture. Purification of dichloromethane and acetonitrile and preparation of tetrabutylammonium perchlorate (TBAP) for electrochemical work were performed as before. ${ }^{9}$

Preparation of Complexes. [ $\left.\mathrm{Rh}\left(\mathrm{PPh}_{3}\right)_{2}\left(\mathrm{CNO}-\mathbf{N E t}_{2}\right) \mathrm{Cl}\right]$. paraNitrobenzaldehyde semicarbazone $(23 \mathrm{mg}, 0.11 \mathrm{mmol})$ was taken in toluene $(40 \mathrm{~mL})$ and to it was added triethylamine $(70 \mathrm{mg}, 0.70$ mmol). ${ }^{10}$ The flask was purged with a stream of nitrogen for 10 min. Then, $\left[\mathrm{Rh}\left(\mathrm{PPh}_{3}\right)_{3} \mathrm{Cl}\right](100 \mathrm{mg}, 0.11 \mathrm{mmol})$ was added, and the mixture was heated at reflux under a nitrogen atmosphere for $6 \mathrm{~h}$ to yield an orange solution. Evaporation of this solution gave a yellowish-orange solid, which was subjected to purification by thin-layer chromatography on a silica plate. With benzene as the eluant (CAUTION! Benzene is carcinogenic.), an orange band separated, which was extracted with acetonitrile, and evaporation of this extract gave $\left[\mathrm{Rh}\left(\mathrm{PPh}_{3}\right)_{2}\left(\mathrm{CNO}-\mathrm{NEt}_{2}\right) \mathrm{Cl}\right]$ as a crystalline orange solid. Yield: $75 \%$.

(8) Osborn, J. A.; Wilkinson, G. Inorg. Synth. 1967, 10, 67.

(9) (a) Sawyer, D. T.; Roberts, J. L., Jr. Experimental Electrochemistry for Chemists; Wiley: New York, 1974; pp 167-215. (b) Walter, M.; Ramaley, L. Anal. Chem. 1973, 45, 165.

(10) Addition of an equivalent quantity of diethylamine ( $\left.\mathrm{NHEt}_{2}\right)$ also gave the same product. 
Pal et al.

The other two $\left[\mathrm{Rh}\left(\mathrm{PPh}_{3}\right)_{2}\left(\mathrm{CNO}-\mathrm{NR}_{2}\right) \mathrm{Cl}\right]\left(\mathrm{R}={ }^{\mathrm{i}} \mathrm{Pr}\right.$ and $\left.{ }^{\mathrm{n}} \mathrm{Bu}\right)$ complexes were prepared by following the same procedure using, respectively, diisopropylamine and tri- $n$-butylamine instead of triethylamine. The yield was $72 \%$ for the $\mathrm{R}={ }^{i} \mathrm{Pr}$ complex and $78 \%$ for the $\mathrm{R}={ }^{\mathrm{n}} \mathrm{Bu}$ complex.

$\left[\mathbf{R h}\left(\mathbf{P P h}_{3}\right)_{2}\left(\mathbf{O N O}^{\mathbf{1}-\mathbf{N E t}} \mathbf{2}_{2}\right) \mathbf{C l}\right]$. Salicylaldehyde semicarbazone (30 mg, $0.17 \mathrm{mmol})$ was taken in toluene $(40 \mathrm{~mL})$ and to it was added triethylamine $(90 \mathrm{mg}, 0.90 \mathrm{mmol}) .{ }^{10}$ The flask was purged with a stream of nitrogen for $10 \mathrm{~min}$. Then, $\left[\mathrm{Rh}\left(\mathrm{PPh}_{3}\right)_{3} \mathrm{Cl}\right](100$ $\mathrm{mg}, 0.11 \mathrm{mmol}$ ) was added, and the mixture was heated at reflux under a nitrogen atmosphere for $8 \mathrm{~h}$ to yield an orange solution. Evaporation of this solution gave a yellowish-orange solid, which was subjected to purification by thin-layer chromatography on a silica plate. Using 10:1 benzene-acetonitrile as the eluant, a yellowish-orange band separated, which was extracted with 1:1 dichloromethane-acetonitrile. Upon evaporation of this extract, beautiful yellowish-orange crystals were obtained. As these crystals were found to contain the $\left[\mathrm{Rh}\left(\mathrm{PPh}_{3}\right)_{2} \mathrm{Cl}_{2}\right]$ complex in addition to $\left[\mathrm{Rh}\left(\mathrm{PPh}_{3}\right)_{2}\left(\mathrm{ONO}^{1}-\mathrm{NEt}_{2}\right) \mathrm{Cl}\right]$ (vide infra), they were again dissolved in dichloromethane and purified for the second time by thin-layer chromatography on a silica plate. Using only benzene as the eluant, a minor yellow band moved first followed by a major orange band. The orange band was extracted with acetonitrile, and evaporation of this extract gave $\left[\mathrm{Rh}\left(\mathrm{PPh}_{3}\right)_{2}\left(\mathrm{ONO}^{1}-\mathrm{NEt}_{2}\right) \mathrm{Cl}\right]$ as an orange solid. Yield: $52 \%$.

The other $\left[\mathrm{Rh}\left(\mathrm{PPh}_{3}\right)_{2}\left(\mathrm{ONO}^{n}-\mathrm{NR}_{2}\right) \mathrm{Cl}\right]$ complexes were prepared by following the same procedure using the appropriate semicarbazone and amine $\left(\mathrm{NR}_{2} \mathrm{R}^{\prime}\right)$ instead of salicylaldehyde semicarbazone and triethylamine, respectively. Each complex was purified by chromatography twice as described. Yields varied in the range $50-55 \%$.

Physical Measurements. Microanalyses (C, H, N) were performed using a Heraeus Carlo Erba 1108 elemental analyzer. IR spectra were obtained on a Shimadzu FTIR-8300 spectrometer with samples prepared as $\mathrm{KBr}$ pellets. Electronic spectra were recorded on a JASCO V-570 spectrophotometer. Magnetic susceptibilities were measured using a PAR 155 vibrating sample magnetometer fitted with a Walker scientific L75FBAL magnet. ${ }^{1} \mathrm{H}$ NMR spectra were recorded in $\mathrm{CDCl}_{3}$ solution on either a Bruker DRX 500 or a Bruker Avance DPX 300 NMR spectrometer using TMS as the internal standard. Electrochemical measurements were made using a CH Instruments model 600A electrochemical analyzer. A platinum disk working electrode, a platinum wire auxiliary electrode, and an aqueous saturated calomel reference electrode (SCE) were used in a three electrode configuration. All electrochemical experiments were performed under a dinitrogen atmosphere. All electrochemical data were collected at $298 \mathrm{~K}$ and are uncorrected for junction potentials.

Crystallography of $\left[\mathbf{R h}\left(\mathbf{P P h}_{3}\right)_{2}\left(\mathbf{C N O}-\mathbf{N E t}_{2}\right) \mathbf{C l}\right]$. Single crystals of $\left[\mathrm{Rh}\left(\mathrm{PPh}_{3}\right)_{2}\left(\mathrm{CNO}-\mathrm{NEt}_{2}\right) \mathrm{Cl}\right]$ were obtained by slow evaporation of an acetonitrile solution of the complex. Selected crystal data and data collection parameters are given in Table 1. Data were collected on an Enraf Nonius CAD-4 diffractometer using graphite monochromated Mo K $\alpha$ radiation $(\lambda=0.71069 \AA)$ by $\theta-2 \theta$ scans $\left(1.78^{\circ}<\theta<22.50^{\circ}\right)$. X-ray data reduction and structure solution and refinement were done using the SHELXS-97 and SHELXL97 programs. ${ }^{11}$ The structure was solved by direct methods.

Crystallography of $\left[\mathrm{Rh}\left(\mathrm{PPh}_{3}\right)_{\mathbf{2}}\left(\mathrm{ONO}^{2}-\mathrm{NEt}_{2}\right) \mathrm{Cl}\right]$. Single crystals of $\left[\mathrm{Rh}\left(\mathrm{PPh}_{3}\right)_{2}\left(\mathrm{ONO}^{2}-\mathrm{NEt}_{2}\right) \mathrm{Cl}\right]$ were obtained by slow evapora-

(11) Sheldrick, G. M. SHELXS-97 and SHELXL-97, Fortran programs for crystal structure solution and refinement; University of Göttingen, Göttingen, Germany, 1997.
Table 1. Crystallographic Data for $\left[\mathrm{Rh}\left(\mathrm{PPh}_{3}\right)_{2}\left(\mathrm{CNO}-\mathrm{NEt}_{2}\right) \mathrm{Cl}\right]$ and $\left[\mathrm{Rh}\left(\mathrm{PPh}_{3}\right)_{2}\left(\mathrm{ONO}^{2}-\mathrm{NEt}_{2}\right) \mathrm{Cl}\right.$

\begin{tabular}{lll}
\hline empirical formula & $\mathrm{C}_{50} \mathrm{H}_{47} \mathrm{ClN}_{5} \mathrm{O}_{3} \mathrm{P}_{2} \mathrm{Rh}$ & $\mathrm{C}_{134} \mathrm{H}_{124} \mathrm{Cl}_{4} \mathrm{~N}_{6} \mathrm{O}_{4} \mathrm{P}_{6} \mathrm{Rh}_{3}$ \\
fw & 965.41 & 2518.74 \\
space group & monoclinic, $I 2 / a$ & triclinic, $P \overline{1}$ \\
$a, \AA$ & $24.288(5)$ & $12.1627(1)$ \\
$b, \AA$ & $17.010(5)$ & $16.4398(2)$ \\
$c, \AA$ & $25.114(5)$ & $16.5077(2)$ \\
$\alpha$, deg & $90.00(5)$ & $112.3859(5)$ \\
$\beta$, deg & $114.370(5)$ & $105.4037(4)$ \\
$\gamma$, deg & $90.00(5)$ & $90.9540(5)$ \\
$V, \AA \AA^{3}$ & $9451(4)$ & $2916.56(6)$ \\
$Z$ & 4 & 1 \\
$\lambda, \AA$ & 0.71069 & 0.71073 \\
crystal size, mm $^{3}$ & $0.20 \times 0.20 \times 0.20$ & $0.10 \times 0.10 \times 0.07$ \\
$T, \mathrm{~K}^{-1}$ & 293 & 150 \\
$\mu, \mathrm{mm}^{-1}$ & 0.532 & 0.652 \\
$\mathrm{R}^{a}$ & 0.0860 & 0.0530 \\
wR2 $^{b}$ & 0.1666 & 0.1268 \\
$\mathrm{GOF}^{c}$ & 1.086 & 1.040
\end{tabular}

${ }^{a} \mathrm{R} 1=\sum|| F_{\mathrm{o}}|-| F_{\mathrm{c}}|| / \sum\left|F_{\mathrm{o}}\right| .{ }^{b} \mathrm{wR} 2=\left[\sum\left[w\left(F_{\mathrm{o}}{ }^{2}-F_{\mathrm{c}}{ }^{2}\right)^{2}\right] / \sum\left[w\left(F_{\mathrm{o}}{ }^{2}\right)^{2}\right]\right]^{1 / 2}$. ${ }^{c} \mathrm{GOF}=\left[\sum\left[w\left(F_{\mathrm{o}}^{2}-F_{\mathrm{c}}^{2}\right)^{2}\right] /(M-N)\right]^{1 / 2}$, where $M$ is the number of reflections and $N$ is the number of parameters refined.

tion of the 1:1 dichloromethane-acetonitrile extract obtained from the first chromatographic purification of the complex (see synthetic procedure). Selected crystal data and data collection parameters are given in Table 1. Data were collected on a Nonius Kappa CCD diffractometer using graphite monochromated Mo K $\alpha$ radiation $(\lambda$ $=0.71073 \AA$ ) by $\phi$ and $\omega$ scans $\left(1.75^{\circ}<\theta<27.50^{\circ}\right)$. X-ray data reduction and structure solution and refinement were done as already stated. These crystals were found to contain a square planar $\left[\mathrm{Rh}\left(\mathrm{PPh}_{3}\right)_{2} \mathrm{Cl}_{2}\right]$ complex molecule per two molecules of the $\left[\mathrm{Rh}\left(\mathrm{PPh}_{3}\right)_{2}\left(\mathrm{ONO}^{2}-\mathrm{NEt}_{2}\right) \mathrm{Cl}\right]$ complex. As the observed structural parameters for the $\left[\mathrm{Rh}\left(\mathrm{PPh}_{3}\right)_{2} \mathrm{Cl}_{2}\right]$ fragment compare well with those reported earlier, ${ }^{12}$ the structural discussion in the text includes only the $\left[\mathrm{Rh}\left(\mathrm{PPh}_{3}\right)_{2}\left(\mathrm{ONO}^{2}-\mathrm{NEt}_{2}\right) \mathrm{Cl}\right]$ complex.

\section{Results and Discussion}

Reaction of $\left[\mathrm{Rh}\left(\mathrm{PPh}_{3}\right)_{3} \mathrm{Cl}\right]$ was carried out with all the semicarbazones (1) in refluxing toluene in the presence of $\mathrm{NEt}_{3}$. However, only the reaction with para-nitrobenzaldehyde semicarbazone proceeded smoothly to afford an orange complex in decent yield. ${ }^{7}$ Preliminary characterizations (microanalysis, IR, and NMR) on this complex failed to indicate any unambiguous formulation for it. Identity of the complex has been revealed by its structure determination by $\mathrm{X}$-ray crystallography. The structure is displayed in Figure 1 , and selected bond parameters are listed in Table 2. The structure shows that during the course of the synthetic reaction the para-nitrobenzaldehyde semicarbazone has undergone an interesting chemical transformation, viz. the $\mathrm{NH}_{2}$ group of the semicarbazone has been replaced by a $\mathrm{NEt}_{2}$ group provided by the base $\left(\mathrm{NEt}_{3}\right)$. The modified semicarbazone is coordinated to rhodium, via dissociation of two protons, as a dianionic C,N,O-donor ligand. Orthometalation has taken place from the phenyl ring of the modified semicarbazone. Two triphenylphosphines and a chloride are also bound to the metal center. This complex is therefore formulated as $\left[\mathrm{Rh}\left(\mathrm{PPh}_{3}\right)_{2}\left(\mathrm{CNO}-\mathrm{NEt}_{2}\right) \mathrm{Cl}\right]$, where $\mathrm{CNO}-\mathrm{NEt}_{2}$ represents the coordinated semicarbazone. The

(12) Ogle, C. A.; Masterman, T. C.; Hubbard, J. L. J. Chem. Soc., Chem. Commun. 1990, 1733.

4340 Inorganic Chemistry, Vol. 42, No. 14, 2003 


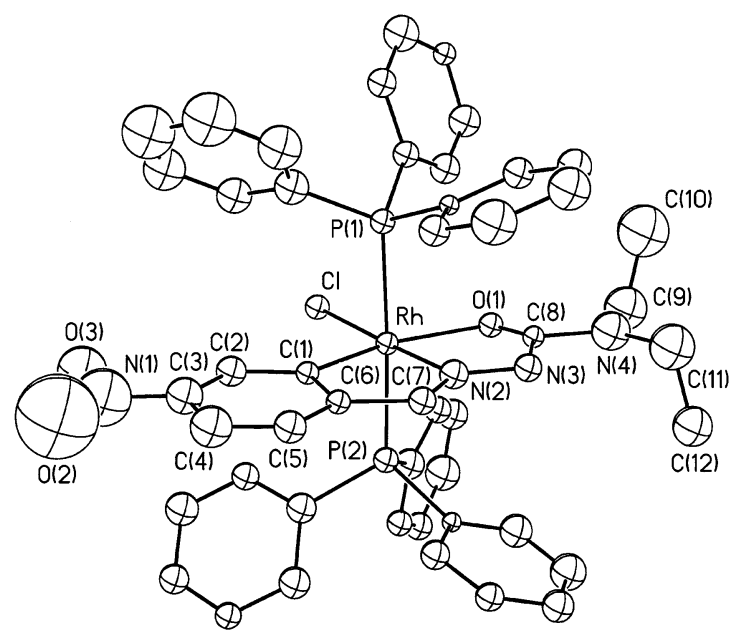

Figure 1. View of the $\left[\mathrm{Rh}\left(\mathrm{PPh}_{3}\right)_{2}\left(\mathrm{CNO}-\mathrm{NEt}_{2}\right) \mathrm{Cl}\right]$ complex.

Table 2. Selected Bond Distances and Bond Angles for $\left[\mathrm{Rh}\left(\mathrm{PPh}_{3}\right)_{2}\left(\mathrm{CNO}-\mathrm{NEt}_{2}\right) \mathrm{Cl}\right]$ and $\left[\mathrm{Rh}\left(\mathrm{PPh}_{3}\right)_{2}\left(\mathrm{ONO}^{2}-\mathrm{NEt}_{2}\right) \mathrm{Cl}\right]$

\begin{tabular}{|c|c|c|c|}
\hline \multicolumn{4}{|c|}{$\left[\mathrm{Rh}\left(\mathrm{PPh}_{3}\right)_{2}\left(\mathrm{CNO}-\mathrm{NEt}_{2}\right) \mathrm{Cl}\right]$} \\
\hline \multicolumn{4}{|c|}{ Bond Distances $(\AA)$} \\
\hline $\mathrm{Rh}-\mathrm{C}(1)$ & $1.989(12)$ & $\mathrm{Rh}-\mathrm{O}(1)$ & $2.189(9)$ \\
\hline $\mathrm{Rh}-\mathrm{P}(1)$ & $2.371(3)$ & $\mathrm{Rh}-\mathrm{P}(2)$ & $2.360(3)$ \\
\hline $\mathrm{Rh}-\mathrm{Cl}$ & $2.381(4)$ & $\mathrm{Rh}-\mathrm{N}(2)$ & $1.968(10)$ \\
\hline$C(7)-N(2)$ & $1.328(15)$ & $\mathrm{N}(2)-\mathrm{N}(3)$ & $1.351(14)$ \\
\hline $\mathrm{C}(8)-\mathrm{N}(3)$ & $1.35(2)$ & $\mathrm{C}(8)-\mathrm{O}(1)$ & $1.26(2)$ \\
\hline $\mathrm{C}(8)-\mathrm{N}(4)$ & $1.384(19)$ & $\mathrm{C}(9)-\mathrm{N}(4)$ & $1.47(2)$ \\
\hline $\mathrm{C}(11)-\mathrm{N}(4)$ & $1.43(2)$ & & \\
\hline \multicolumn{4}{|c|}{ Bond Angles (deg) } \\
\hline $\mathrm{P}(2)-\mathrm{Rh}-\mathrm{P}(1)$ & $177.61(14)$ & $\mathrm{N}(2)-\mathrm{Rh}-\mathrm{C}(1)$ & $83.1(5)$ \\
\hline $\mathrm{N}(2)-\mathrm{Rh}-\mathrm{Cl}(1)$ & $177.2(2)$ & $\mathrm{N}(2)-\mathrm{Rh}-\mathrm{O}(1)$ & $76.3(5)$ \\
\hline $\mathrm{C}(1)-\mathrm{Rh}-\mathrm{O}(1)$ & $159.4(5)$ & & \\
\hline \multicolumn{4}{|c|}{$\left[\mathrm{Rh}\left(\mathrm{PPh}_{3}\right)_{2}\left(\mathrm{ONO}^{2}-\mathrm{NEt}_{2}\right) \mathrm{Cl}\right]$} \\
\hline \multicolumn{4}{|c|}{ Bond Distances $(\AA)$} \\
\hline $\mathrm{Rh}(1)-\mathrm{N}(1)$ & $1.974(3)$ & $\mathrm{Rh}(1)-\mathrm{O}(1)$ & $1.996(2)$ \\
\hline $\mathrm{Rh}(1)-\mathrm{O}(2)$ & $2.034(2)$ & $\mathrm{Rh}(1)-\mathrm{P}(1)$ & $2.3833(11)$ \\
\hline $\mathrm{Rh}(1)-\mathrm{P}(2)$ & $2.3786(10)$ & $\mathrm{Rh}(1)-\mathrm{Cl}(1)$ & $2.3795(10)$ \\
\hline $\mathrm{O}(1)-\mathrm{C}(1)$ & $1.324(4)$ & $\mathrm{C}(7)-\mathrm{N}(1)$ & $1.306(5)$ \\
\hline $\mathrm{N}(1)-\mathrm{N}(2)$ & $1.398(4)$ & $\mathrm{C}(9)-\mathrm{N}(2)$ & $1.340(5)$ \\
\hline $\mathrm{C}(9)-\mathrm{O}(2)$ & $1.303(5)$ & $\mathrm{C}(9)-\mathrm{N}(3)$ & $1.358(5)$ \\
\hline $\mathrm{C}(10)-\mathrm{N}(3)$ & $1.364(6)$ & $\mathrm{C}(12)-\mathrm{N}(3)$ & $1.460(6)$ \\
\hline \multicolumn{4}{|c|}{ Bond Angles (deg) } \\
\hline $\mathrm{P}(1)-\mathrm{Rh}(1)-\mathrm{P}(2)$ & $177.79(4)$ & $\mathrm{N}(1)-\mathrm{Rh}(1)-\mathrm{O}(1)$ & $95.18(12)$ \\
\hline $\mathrm{N}(1)-\mathrm{Rh}(1)-\mathrm{Cl}(1)$ & $173.37(10)$ & $\mathrm{N}(1)-\mathrm{Rh}(1)-\mathrm{O}(2)$ & $80.78(12)$ \\
\hline $\mathrm{O}(1)-\mathrm{Rh}(1)-\mathrm{O}(2)$ & $175.41(10)$ & & \\
\hline
\end{tabular}

$\mathrm{CNOP}_{2} \mathrm{Cl}$ coordination sphere around rhodium is a distorted octahedron, as reflected in all the bond parameters around the metal center. The tricoordinated semicarbazone, rhodium, and chloride have constituted one equatorial plane, and the two $\mathrm{PPh}_{3}$ ligands have taken up the axial positions and, hence, they are mutually trans. The $\mathrm{Rh}-\mathrm{C}, \mathrm{Rh}-\mathrm{N}, \mathrm{Rh}-\mathrm{P}$, and $\mathrm{Rh}-\mathrm{Cl}$ distances are all quite normal, as usually observed in complexes of rhodium(III) containing these bonds. ${ }^{6}{ }^{13}$ However, the $\mathrm{Rh}-\mathrm{O}(1)$ length is a bit longer than usual. ${ }^{13 \mathrm{~b}, 14}$ The observed $\mathrm{C}(8)-\mathrm{O}(1)$ distance is intermediate between $\mathrm{C}=\mathrm{O}$ and $\mathrm{C}-\mathrm{O}$. The $\mathrm{C}(8)-\mathrm{N}(3)$ distance similarly indicates a bond order which is between a single and double

(13) (a) Garcia, M. P.; Jimenez, M. V.; Lahoz, F. J.; Lopez, J. A.; Oro, L. A. J. Chem. Soc., Dalton Trans. 1998, 421. (b) Bennett, M. J.; Donaldson, P. B. Inorg. Chem. 1977, 16, 1581.

(14) Das, A.; Basuli, F.; Peng, S. M.; Bhattacharya, S. Inorg. Chem. 2002, $41,440$.
Scheme 1. Probable Steps in the Formation of the $\left[\mathrm{Rh}\left(\mathrm{PPh}_{3}\right)_{2}(\mathrm{CNO}-\right.$ $\left.\mathrm{NR}_{2}\right) \mathrm{Cl}$ ] Complexes

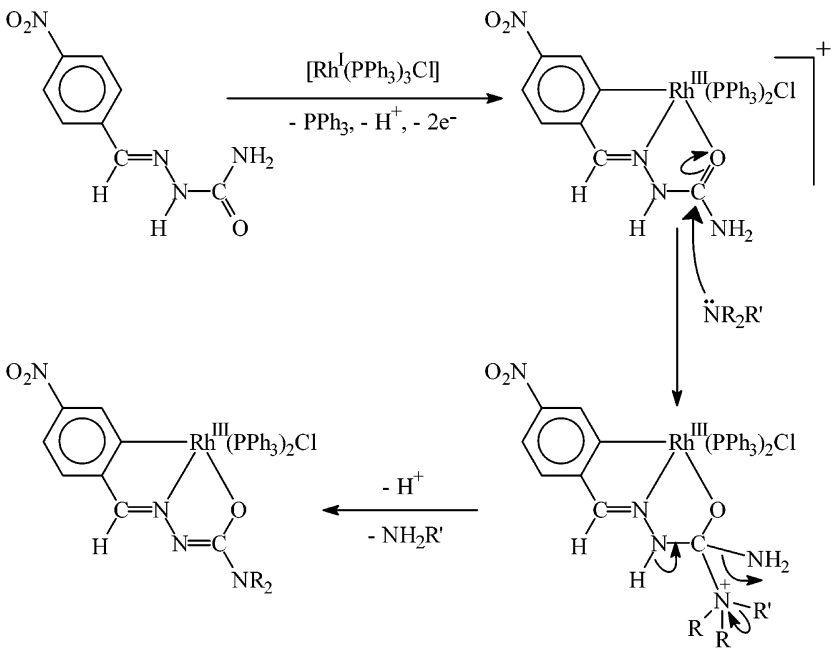

bond. The observed intermediacy in bond orders in the $\mathrm{O}(1)-\mathrm{C}(8)-\mathrm{N}(3)$ fragment is attributable to the possible charge delocalization over this fragment.

The observed chemical transformation of para-nitrobenzaldehyde semicarbazone is not only unusual but also, to our knowledge, unprecedented. Encouraged by this result, reaction of the para-nitrobenzaldehyde semicarbazone with $\left[\mathrm{Rh}\left(\mathrm{PPh}_{3}\right)_{3} \mathrm{Cl}\right]$ was also carried out in the presence of another trialkylamine $\left(\mathrm{N}^{\mathrm{n}} \mathrm{Bu}_{3}\right)$ and two dialkylamines $\left(\mathrm{NHR}_{2}, \mathrm{R}=\right.$ $\left.\mathrm{Et},{ }^{\mathrm{P}} \mathrm{Pr}\right)$ in order to check whether the semicarbazone reacts with these amines and undergoes a similar transformation. Each of these reactions indeed gave the expected complex of type $\left[\mathrm{Rh}\left(\mathrm{PPh}_{3}\right)_{2}\left(\mathrm{CNO}-\mathrm{NR}_{2}\right) \mathrm{Cl}\right]\left(\mathrm{R}=\mathrm{Et},{ }^{\mathrm{i}} \mathrm{Pr},{ }^{\mathrm{n}} \mathrm{Bu}\right)$. It is interesting to note here that the same $\left[\mathrm{Rh}\left(\mathrm{PPh}_{3}\right)_{2}(\mathrm{CNO}-\right.$ $\left.\mathrm{NEt}_{2}\right) \mathrm{Cl}$ ] complex is obtained using diethylamine or triethylamine. Elemental $(\mathrm{C}, \mathrm{H}, \mathrm{N})$ analytical data of all these complexes agree well with their formulations (Table S1). As all the $\left[\mathrm{Rh}\left(\mathrm{PPh}_{3}\right)_{2}\left(\mathrm{CNO}-\mathrm{NR}_{2}\right) \mathrm{Cl}\right]$ complexes have been prepared by following similar procedures and as they show similar properties (vide infra), the other two $\left[\mathrm{Rh}\left(\mathrm{PPh}_{3}\right)_{2}\right.$ $\left.\left(\mathrm{CNO}-\mathrm{NR}_{2}\right) \mathrm{Cl}\right]\left(\mathrm{R}={ }^{\mathrm{i}} \mathrm{Pr},{ }^{\mathrm{n}} \mathrm{Bu}\right)$ complexes are assumed to have a similar structure as $\left[\mathrm{Rh}\left(\mathrm{PPh}_{3}\right)_{2}\left(\mathrm{CNO}-\mathrm{NEt}_{2}\right) \mathrm{Cl}\right]$.

The mechanism of the interesting chemical transformation of para-nitrobenzaldehyde semicarbazone is not completely clear to us. However, that the observed transformation has been mediated by the metal center is apparent from the fact that treatment of the para-nitrobenzaldehyde semicarbazone with the base $\left(\mathrm{NR}_{2} \mathrm{R}^{\prime}\right)$ alone in refluxing toluene (for $6 \mathrm{~h}$ ) failed to bring about any such transformation. The sequences illustrated in Scheme 1 thus seem probable. In the initial step, the semicarbazone coordinates to trivalent rhodium as a monoanionic C,N,O-donor via loss of one phenyl proton. This particular coordination mode of the para-nitrobenzaldehyde semicarbazone was observed in its ruthenium complex. ${ }^{4 \mathrm{c}}$ However, isolation of this intermediate has not been possible in the present case. Nucleophilic attack by the amine $\left(\mathrm{NR}_{2} \mathrm{R}^{\prime}\right)$ at the carbonyl carbon then takes place, which is believed to be the crucial step. The carbonyl carbon in the uncoordinated ligand (1) is similar to that in urea, and hence, it does not appear to be electropositive enough so as 
Pal et al.

Table 3. ${ }^{1} \mathrm{H}$ NMR Data of the Complexes

\begin{tabular}{|c|c|c|c|c|}
\hline \multirow[b]{3}{*}{ compd } & \multicolumn{4}{|c|}{ chemical shift in ppm } \\
\hline & \multirow[b]{2}{*}{$\mathrm{PPh}_{3}$} & \multicolumn{3}{|c|}{ semicarbazone } \\
\hline & & $\operatorname{aromatic~proton~}^{a}$ & azomethine proton & $\mathrm{R}$ \\
\hline$\left[\mathrm{Rh}\left(\mathrm{PPh}_{3}\right)_{2}\left(\mathrm{CNO}-\mathrm{NEt}_{2}\right) \mathrm{Cl}\right]$ & $7.17-7.56$ & $6.60(\mathrm{~d}, 8), 7.46(\mathrm{~d}, 8), 7.91(\mathrm{~s})$ & 6.56 & $0.76,2.99$ \\
\hline$\left[\mathrm{Rh}\left(\mathrm{PPh}_{3}\right)_{2}\left(\mathrm{CNO}-\mathrm{N}^{i} \mathrm{Pr}_{2}\right) \mathrm{Cl}\right]$ & $7.21-7.55$ & $6.59(\mathrm{~d}, 8), 7.83(\mathrm{~s})$ & 6.50 & 0.87 \\
\hline$\left[\mathrm{Rh}\left(\mathrm{PPh}_{3}\right)_{2}\left(\mathrm{CNO}-\mathrm{N}^{n} \mathrm{Bu}_{2}\right) \mathrm{Cl}\right]$ & $7.22-7.54$ & $6.57(\mathrm{~d}, 8), 7.91(\mathrm{~s})$ & 6.54 & $0.87,1.08,2.76,2.94$ \\
\hline$\left[\mathrm{Rh}\left(\mathrm{PPh}_{3}\right)_{2}\left(\mathrm{ONO}^{1}-\mathrm{NEt}_{2}\right) \mathrm{Cl}\right]$ & $7.21-7.67$ & $6.03(\mathrm{t}, 7), 6.09(\mathrm{~d}, 7), 6.66(\mathrm{~d}, 8), 6.74(\mathrm{t}, 7)$ & 6.52 & $0.60,2.91$ \\
\hline$\left[\mathrm{Rh}\left(\mathrm{PPh}_{3}\right)_{2}\left(\mathrm{ONO}^{1}-\mathrm{N}^{i} \mathrm{Pr}_{2}\right) \mathrm{Cl}\right]$ & $7.21-7.64$ & $6.03(\mathrm{t}, 6), 6.11(\mathrm{~d}, 7), 6.66(\mathrm{~d}, 9), 6.73(\mathrm{t}, 8)$ & 6.50 & $0.90,1.08$ \\
\hline$\left[\mathrm{Rh}\left(\mathrm{PPh}_{3}\right)_{2}\left(\mathrm{ONO}^{1}-\mathrm{N}^{n} \mathrm{Bu}_{2}\right) \mathrm{Cl}\right]$ & $7.20-7.73$ & $6.04(\mathrm{t}, 6), 6.10(\mathrm{~d}, 6), 6.66(\mathrm{~d}, 8), 6.74(\mathrm{t}, 7)$ & 6.48 & $0.81,0.97,2.83$ \\
\hline$\left[\mathrm{Rh}\left(\mathrm{PPh}_{3}\right)_{2}\left(\mathrm{ONO}^{2}-\mathrm{NEt}_{2}\right) \mathrm{Cl}\right]$ & $7.20-7.64$ & $6.09(\mathrm{gn}, 4), 6.56(\mathrm{~d}, 8), 6.70(\mathrm{~d}, 4)$ & $1.81^{b}$ & $0.61,2.93$ \\
\hline$\left[\mathrm{Rh}\left(\mathrm{PPh}_{3}\right)_{2}\left(\mathrm{ONO}^{2}-\mathrm{N}^{i} \mathrm{Pr}_{2}\right) \mathrm{Cl}\right]$ & $7.19-7.70$ & $6.09(\mathrm{qn}, 4), 6.56(\mathrm{~d}, 8), 6.70(\mathrm{~d}, 4)$ & $1.80^{b}$ & $0.87,1.06$ \\
\hline$\left[\mathrm{Rh}\left(\mathrm{PPh}_{3}\right)_{2}\left(\mathrm{ONO}^{2}-\mathrm{N}^{n} \mathrm{Bu}_{2}\right) \mathrm{Cl}\right]$ & $7.20-7.75$ & $6.09(\mathrm{gn}, 4), 6.57(\mathrm{~d}, 8), 6.70(\mathrm{~d}, 3)$ & $1.79^{b}$ & $0.85,0.93,2.84$ \\
\hline$\left[\mathrm{Rh}\left(\mathrm{PPh}_{3}\right)_{2}\left(\mathrm{ONO}^{3}-\mathrm{NEt}_{2}\right) \mathrm{Cl}\right]$ & $7.13-7.70$ & $6.84(\mathrm{~d}, 9), 7.01(\mathrm{t}, 7), 7.40(\mathrm{t}, 8)$ & & $0.67,2.92$ \\
\hline$\left[\mathrm{Rh}\left(\mathrm{PPh}_{3}\right)_{2}\left(\mathrm{ONO}^{3}-\mathrm{N}^{i} \mathrm{Pr}_{2}\right) \mathrm{Cl}\right]$ & $7.07-7.63$ & $6.84(\mathrm{~d}, 9), 7.01(\mathrm{t}, 7), 7.40(\mathrm{t}, 8)$ & & 0.79 \\
\hline$\left[\mathrm{Rh}\left(\mathrm{PPh}_{3}\right)_{2}\left(\mathrm{ONO}^{3}-\mathrm{N}^{n} \mathrm{Bu}_{2}\right) \mathrm{Cl}\right]$ & $7.13-7.73$ & 6.84(d, 9), 7.02(t, 7), 7.40(t, 8) & & $0.85,1.06,2.86$ \\
\hline
\end{tabular}

to initiate an attack by the amine $\left(\mathrm{NR}_{2} \mathrm{R}^{\prime}\right)$. Coordination of the semicarbazone ligand to trivalent rhodium as a monoanionic $\mathrm{C}, \mathrm{N}, \mathrm{O}$-donor in the first step must have enhanced the electrophilicity of the carbonyl carbon to such an extent that it undergoes facile attack by the nucleophile $\left(\mathrm{NR}_{2} \mathrm{R}^{\prime}\right)$. The nitro group in the phenyl ring also appears to play a vital role in this reaction. Being a strong electron-withdrawing group, it enhances dissociability of the phenyl protons and thus favors formation of the $\mathrm{Rh}-\mathrm{C}$ bond, which is also responsible, to some extent, for increasing the electropositive nature of the carbonyl carbon. Indirect evidence of the influence of the nitro group comes from the fact that reactions of $\left[\mathrm{Rh}\left(\mathrm{PPh}_{3}\right)_{3} \mathrm{Cl}\right]$ with semicarbazones of other parasubstituted benzaldehydes $\left(1, X \neq \mathrm{NO}_{2}\right)$, where the substituent is less electron-withdrawing than the nitro group (e.g., $\mathrm{OCH}_{3}, \mathrm{CH}_{3}, \mathrm{H}$, and $\mathrm{Cl}$ ), do not afford a similar product. ${ }^{7}$ Thus, the observed transformation of the para-nitrobenzaldehyde semicarbazone appears to be directed by the combined influence of the nitro group in it and its coordination to rhodium(III) in the initial step.

All the $\left[\mathrm{Rh}\left(\mathrm{PPh}_{3}\right)_{2}\left(\mathrm{CNO}-\mathrm{NR}_{2}\right) \mathrm{Cl}\right]$ complexes are diamagnetic, which corresponds to the trivalent state of rhodium (low-spin $\mathrm{d}^{6}, S=0$ ) in these complexes. ${ }^{1} \mathrm{H}$ NMR spectra of these complexes show all the expected signals (Table 3). The signals from the phenyl protons of the $\mathrm{PPh}_{3}$ ligands are observed as broad signals within 7.1-7.6 ppm. The azomethine proton signal is observed near $6.5 \mathrm{ppm}$. Among the three expected aromatic proton signals (one singlet and two doublets) from the nitro-phenyl ring of the $\mathrm{CNO}-\mathrm{NR}_{2}$ ligand, two (one singlet and one doublet) are clearly observed within 6.57-7.91 ppm in all the three complexes, while the third (doublet) signal is observed in only one complex. It could not be detected in the other two complexes because of its overlap with the $\mathrm{PPh}_{3}$ signals. Signals for the alkyl groups of the $\mathrm{NR}_{2}$ fragment of the $\mathrm{CNO}-\mathrm{NR}_{2}$ ligands are also observed as broad peaks in the expected region. The ${ }^{1} \mathrm{H}$ NMR spectral data of the $\left[\mathrm{Rh}\left(\mathrm{PPh}_{3}\right)_{2}(\mathrm{CNO}-\right.$ $\left.\mathrm{NR}_{2}\right) \mathrm{Cl}$ ] complexes are therefore consistent with their compositions.

Infrared spectra of the $\left[\mathrm{Rh}\left(\mathrm{PPh}_{3}\right)_{2}\left(\mathrm{CNO}-\mathrm{NR}_{2}\right) \mathrm{Cl}\right] \mathrm{com}-$ plexes show sharp bands near 745,695 , and $520 \mathrm{~cm}^{-1}$ due to the coordinated $\mathrm{PPh}_{3}$ ligands. ${ }^{4 a, 6,15}$ Strong bands are also observed near 1434, 1411, 1329, 1306, 1280, 1227, 1190, and $1094 \mathrm{~cm}^{-1}$ in all these complexes, which are absent in the infrared spectrum of $\left[\mathrm{Rh}\left(\mathrm{PPh}_{3}\right)_{3} \mathrm{Cl}\right]$, and hence, these bands are attributed to the coordinated semicarbazone ligand. Electronic spectra of the $\left[\mathrm{Rh}\left(\mathrm{PPh}_{3}\right)_{2}\left(\mathrm{CNO}-\mathrm{NR}_{2}\right) \mathrm{Cl}\right] \mathrm{com}-$ plexes have been recorded in dichloromethane solution. Each complex uniformly shows three intense absorptions, two in the visible region and one in the ultraviolet region (Table 4). The absorption in the ultraviolet region is believed to be due to a transition within the ligand orbitals. Among the two absorptions in the visible region, the higher energy transition (near $380 \mathrm{~nm}$ ) is relatively less intense, while the lower energy transition (near $490 \mathrm{~nm}$ ) is much more intense. To have an insight into the nature of transitions in the visible region, qualitative EHMO calculations have been performed ${ }^{16}$ on computer generated models of the $\left[\mathrm{Rh}\left(\mathrm{PPh}_{3}\right)_{2}(\mathrm{CNO}-\right.$ $\left.\mathrm{NR}_{2}\right) \mathrm{Cl}$ ] complexes, where phenyl rings of the triphenylphosphines were replaced by hydrogen. The results of these calculations have been found to be similar for all the complexes. A partial MO diagram for a representative complex is shown in Figure 2, and the composition of some selected molecular orbitals of it is given in Table 5. The highest occupied molecular orbital (HOMO) is concentrated almost entirely $(\geq 90 \%)$ on the $\mathrm{NR}_{2}$ fragment of the semicarbazone ligand. The next couple of filled orbitals (HOMO -1 , HOMO -2 , etc.), however, have significant $(\geq 45 \%)$ contribution from the rhodium $t_{2}$-orbitals. The lowest unoccupied molecular orbital (LUMO) has a major $(\geq 95 \%)$ contribution from the semicarbazone ligand and is localized mostly ( $\geq 55 \%$ ) on the nitro group. The next couple of vacant orbitals (LUMO +1 , LUMO +2 , etc.) also have major contributions from the semicarbazone ligand. The lower energy absorption (near $490 \mathrm{~nm}$ ) may therefore be assigned to a transition from the HOMO concentrated on one fragment $\left(\mathrm{NR}_{2}\right)$ of the semicarbazone ligand to the LUMO localized on another fragment $\left(\mathrm{NO}_{2}\right)$ of the same ligand, which is an allowed transition and thus accounts for its high intensity. The second absorption near $380 \mathrm{~nm}$, which is of much less

(15) Das, A. K.; Peng, S. M.; Bhattacharya, S. J. Chem. Soc., Dalton Trans. 2000, 181 .

4342 Inorganic Chemistry, Vol. 42, No. 14, 2003 
Table 4. Electronic Spectral and Cyclic Voltammetric Data

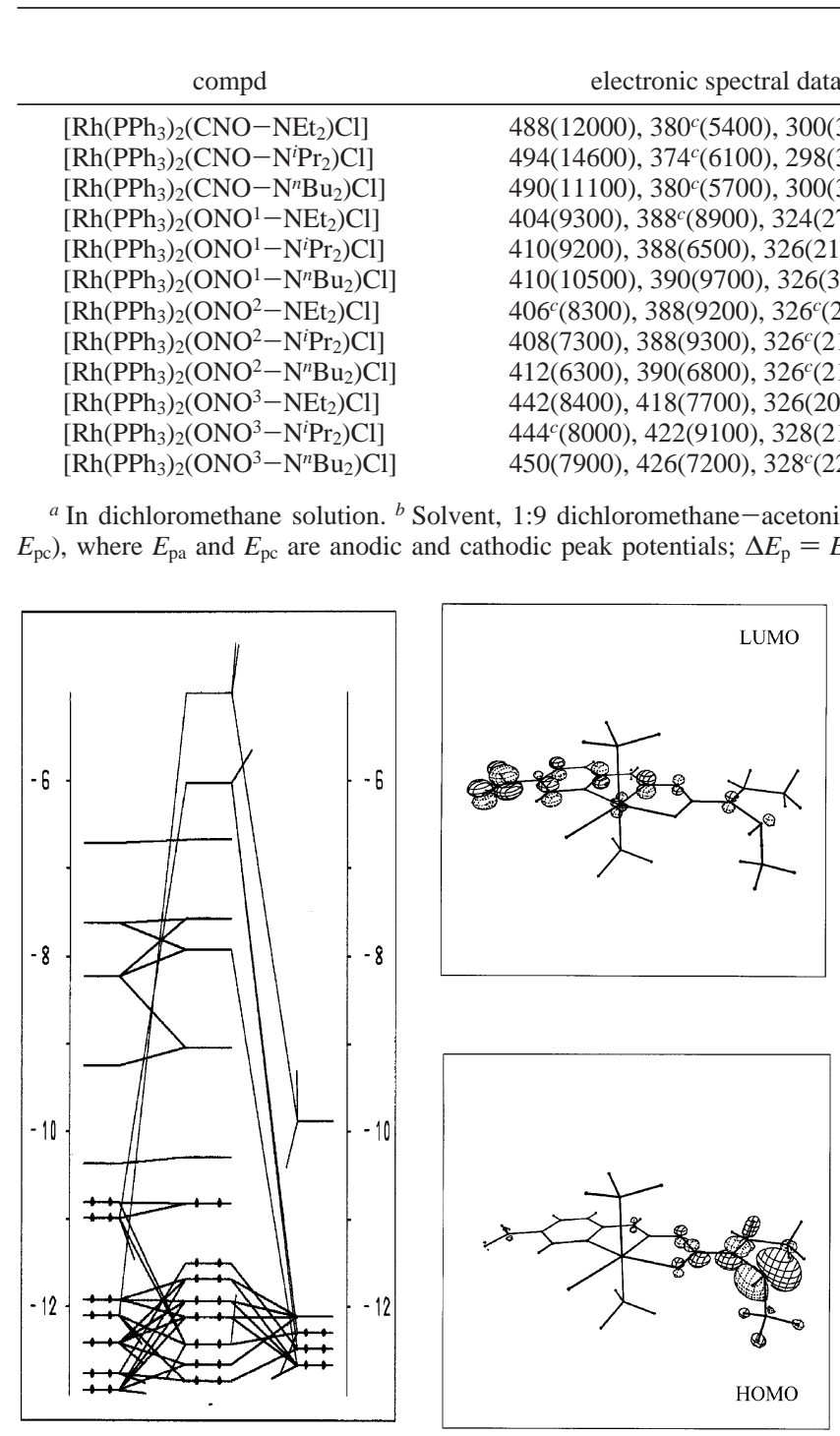

Figure 2. Partial molecular orbital diagram of $\left[\mathrm{Rh}\left(\mathrm{PPh}_{3}\right)_{2}(\mathrm{CNO}-\right.$ $\left.\left.\mathrm{NEt}_{2}\right) \mathrm{Cl}\right]$.

intensity, may be attributed to a transition taking place from the HOMO -1 to one of the vacant orbitals and hence may be regarded as a metal-to-ligand charge-transfer (MLCT) transition.

Electrochemical properties of the $\left[\mathrm{Rh}\left(\mathrm{PPh}_{3}\right)_{2}(\mathrm{CNO}-\right.$ $\mathrm{NR}_{2}$ ) Cl] complexes have been studied by cyclic voltammetry in 1:9 dichloromethane-acetonitrile (0.1 M TBAP) solution. Each complex shows one oxidative response on the positive side of SCE and one reductive response on the negative side. Voltammetric data are given in Table 4, and a selected voltammogram is shown in Figure 3. Keeping the results of the EHMO calculations (vide supra) in view, both the oxidative and reductive responses are assigned to oxidation and reduction of the coordinated semicarbazone ligand. The oxidation is reversible in nature, with a peak-to-peak separation $\left(\Delta E_{\mathrm{p}}\right)$ of $70-80 \mathrm{mV}$, and the anodic peak-current $\left(i_{\mathrm{pa}}\right)$ is almost equal to the cathodic peak-current $\left(i_{\mathrm{pc}}\right)$. The reductive response is irreversible in nature. One-electron stoichiometry of both the redox couples has been established by comparing cyclic voltammetric data ${ }^{b}$

\begin{tabular}{cc}
\hline$E_{1 / 2}, \mathrm{~V}\left(\Delta E_{\mathrm{p}}, \mathrm{mV}\right)$ & $E_{\mathrm{pc}}, \mathrm{V}$ \\
\hline $0.97(80)$ & -1.27 \\
$0.95(80)$ & -1.11 \\
$0.96(70)$ & -1.00 \\
$0.73(70)$ & -1.18 \\
$0.71(80)$ & -1.26 \\
$0.74(68)$ & -1.02 \\
$0.69(70)$ & -1.08 \\
$0.69(73)$ & -1.14 \\
$0.72(64)$ & -1.24 \\
$0.58(70)$ & -1.15 \\
$0.52(80)$ & -1.04 \\
$0.55(80)$ & -1.13
\end{tabular}

$\lambda_{\max }, \mathrm{nm}\left(\epsilon, \mathrm{M}^{-1} \mathrm{~cm}^{-1}\right)$

\section{max}

), 314(27000), 296(26000)

00), 316(32900), 296(32900)

900), 312(30400), 294c (28900)

, 314(23400), 296(24300)

, 264(39300)

), 294(33400), 266(32000)

(2)

$-E_{\mathrm{pc}}$; scan rate, $50 \mathrm{mV} \mathrm{s}^{-1}$. ${ }^{c}$ Shoulder.
S

their current heights $\left(i_{\mathrm{pa}}\right.$ for oxidative response and $i_{\mathrm{pc}}$ for the reductive response) with those of the standard ferroceneferrocenium couple under identical experimental conditions.

The observed chemical transformation of the paranitrobenzaldehyde semicarbazone, which is believed to be initiated by its coordination to trivalent rhodium in a tridentate fashion via loss of one proton (Scheme 1), prompted us to explore other semicarbazone ligands with similar abilities for more of such reactions. A new group of potentially tridentate semicarbazone ligands (3, viz. salicylaldehyde semicarbazone, 2-hydroxyacetophenone semicarbazone, and 2-hydroxynaphthaldehyde semicrbazone) have been selected for this exploration. These semicarbazones are known to serve as O,N,O-donor ligands via loss of two protons. ${ }^{2,17}$ During their reaction with $\left[\mathrm{Rh}\left(\mathrm{PPh}_{3}\right)_{3} \mathrm{Cl}\right]$ in the presence of a base $\left(\mathrm{NR}_{2} \mathrm{R}^{\prime} ; \mathrm{R}=\mathrm{Et},{ }^{\mathrm{i}} \mathrm{Pr},{ }^{\mathrm{n}} \mathrm{Bu}\right.$ and $\mathrm{R}^{\prime}=\mathrm{R}$ or $\mathrm{H}$ ), these ligands are also found to undergo similar chemical transformation as before and afford another group of complexes of type $\left[\mathrm{Rh}\left(\mathrm{PPh}_{3}\right)_{2}\left(\mathrm{ONO}^{n}-\mathrm{NR}_{2}\right) \mathrm{Cl}\right]$, where $\mathrm{ONO}^{n}-\mathrm{NR}_{2}$ refers to the transformed semicarbazones bound to the metal ion as tridentate O,N,O-donor ligands (4). Formation of these complexes has been authenticated by structure determination of one member of this family, viz. $\left[\mathrm{Rh}\left(\mathrm{PPh}_{3}\right)_{2}\left(\mathrm{ONO}^{2}-\mathrm{NEt}_{2}\right) \mathrm{Cl}\right]$, by X-ray crystallography. The structure is shown in Figure 4, and relevant bond parameters are given in Table 2.

The structure shows that the $\mathrm{NH}_{2}$ group of the semicarbazone ligand has been replaced by a $\mathrm{NEt}_{2}$ group and the modified semicarbazone ligand is bound to rhodium as a tridentate O,N,O-donor. The coordinated chloride is sharing the same equatorial plane with the semicarbazone and rhodium, and the $\mathrm{PPh}_{3}$ ligands have occupied the remaining two axial positions. The $\mathrm{NO}_{2} \mathrm{P}_{2} \mathrm{Cl}$ coordination sphere around rhodium is a distorted octahedron. The $\mathrm{Rh}-\mathrm{P}$ and $\mathrm{Rh}-\mathrm{Cl}$ distances compare well with those in the previous structure. The $\mathrm{Rh}-\mathrm{O}(1)$ and $\mathrm{C}(1)-\mathrm{O}(1)$ distances are quite normal, as observed in structurally characterized complexes of rhodium(III) bound to phenolate oxygen. ${ }^{13 b, 18}$ However,

(16) (a) Mealli, C.; Proserpio, D. M. CACAO, version 4.0; Italy, 1994. (b) Mealli, C.; Proserpio, D. M. J. Chem. Educ. 1990, 67, 399.

(17) Thangadurai, T. D.; Natarajan, K. Transition Met. Chem. 2001, 26, 717.

(18) Dutta, S.; Peng, S. M.; Bhattacharya, S. Inorg. Chem. 2000, 39, 2231. 
Pal et al.

Table 5. Composition of Selected Molecular Orbitals

\begin{tabular}{|c|c|c|c|c|c|c|c|}
\hline \multirow[b]{2}{*}{ compd } & \multirow{2}{*}{$\begin{array}{l}\text { contributing } \\
\text { fragments }\end{array}$} & \multicolumn{6}{|c|}{$\%$ contributions of fragments } \\
\hline & & HOMO & HOMO -1 & HOMO -2 & LUMO & LUMO + 1 & $\mathrm{LUMO}+2$ \\
\hline \multirow{2}{*}[\mathrm{Rh}(\mathrm{PPh}_{3})_{2}(\mathrm{CNO}-\mathrm{NEt}_{2})\mathrm{Cl}]{} & $\mathrm{Rh}$ & & $78 \%$ & $49 \%$ & $2 \%$ & $2 \%$ & $3 \%$ \\
\hline & $\mathrm{Cl}$ & & $5 \%$ & $2 \%$ & & & \\
\hline \multirow{3}{*}[\mathrm{Rh}(\mathrm{PPh}_{3})_{2}(\mathrm{ONO}^{1}-\mathrm{NEt}_{2})\mathrm{Cl}]{} & $\mathrm{CNO}-\mathrm{NEt}_{2}$ & $100 \%$ & $17 \%$ & $49 \%$ & $98 \%$ & $98 \%$ & $97 \%$ \\
\hline & $\mathrm{Rh}$ & & $83 \%$ & $45 \%$ & $4 \%$ & & \\
\hline & $\mathrm{Cl}$ & & $5 \%$ & $2 \%$ & & & \\
\hline \multirow{3}{*}[\mathrm{Rh}(\mathrm{PPh}_{3})_{2}(\mathrm{ONO}^{2}-\mathrm{NEt}_{2})\mathrm{Cl}]{} & $\mathrm{ONO}^{1}-\mathrm{NEt}_{2}$ & $100 \%$ & $12 \%$ & $53 \%$ & $96 \%$ & $100 \%$ & $100 \%$ \\
\hline & $\mathrm{Rh}$ & & $81 \%$ & $50 \%$ & $3 \%$ & & \\
\hline & $\mathrm{Cl}$ & & $4 \%$ & $2 \%$ & & & \\
\hline \multirow{4}{*}[\mathrm{Rh}(\mathrm{PPh}_{3})_{2}(\mathrm{ONO}^{3}-\mathrm{NEt}_{2})\mathrm{Cl}]{} & $\mathrm{ONO}^{2}-\mathrm{NEt}_{2}$ & $100 \%$ & $15 \%$ & $48 \%$ & $97 \%$ & $100 \%$ & $100 \%$ \\
\hline & $\mathrm{Rh}$ & & $42 \%$ & $75 \%$ & $3 \%$ & & \\
\hline & $\mathrm{Cl}$ & & & $4 \%$ & & & \\
\hline & $\mathrm{ONO}^{3}-\mathrm{NEt}_{2}$ & $100 \%$ & $58 \%$ & $21 \%$ & $97 \%$ & $100 \%$ & $100 \%$ \\
\hline
\end{tabular}

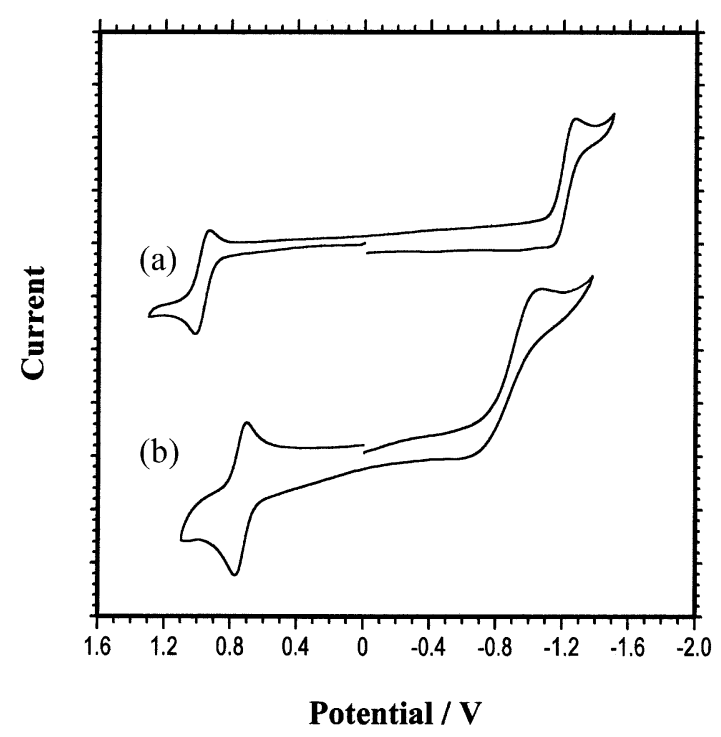

Figure 3. Cyclic voltammograms of (a) $\left[\mathrm{Rh}\left(\mathrm{PPh}_{3}\right)_{2}\left(\mathrm{CNO}-\mathrm{NEt}_{2}\right) \mathrm{Cl}\right]$ and (b) $\left[\mathrm{Rh}\left(\mathrm{PPh}_{3}\right)_{2}\left(\mathrm{ONO}^{1}-\mathrm{N}^{\mathrm{n}} \mathrm{Bu}_{2}\right) \mathrm{Cl}\right]$ in 1:9 dichloromethane-acetonitrile solution $\left(0.1 \mathrm{M}\right.$ TBAP) at a scan rate of $50 \mathrm{mV} \mathrm{s}^{-1}$.

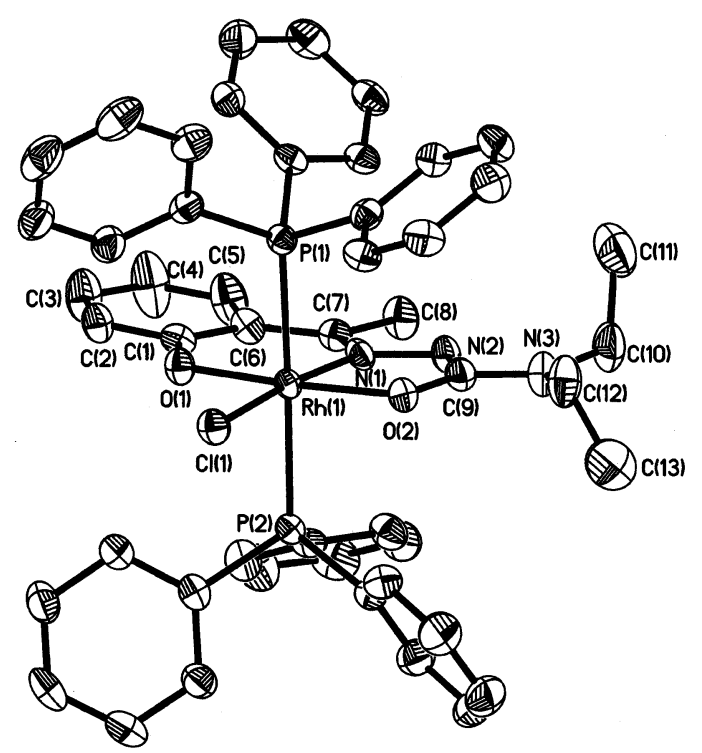

Figure 4. View of the $\left[\mathrm{Rh}\left(\mathrm{PPh}_{3}\right)_{2}\left(\mathrm{ONO}^{2}-\mathrm{NEt}_{2}\right) \mathrm{Cl}\right]$ complex.

lengths of the other bonds in the $\mathrm{Rh}\left(\mathrm{ONO}^{2}-\mathrm{NEt}_{2}\right)$ fragment are observed to be significantly different from those of the corresponding bonds in the $\mathrm{Rh}\left(\mathrm{CNO}-\mathrm{NEt}_{2}\right)$ fragment of the previous structure, and this difference is attributable to the difference in ligand nature and size of the chelate rings. The observed chemical transformation of these semicarbazone ligands (3) is believed to be initiated by their coordination of rhodium(III) as a monoanionic O,N,O-donor via dissociation of only the phenolic proton (5). Such a coordination mode of these semicarbazone ligands $(\mathbf{3})$ is well documented in the literature. ${ }^{3 e}$ Attack of the amine $\left(\mathrm{NR}_{2} \mathrm{R}^{\prime}\right)$ at the carbonyl

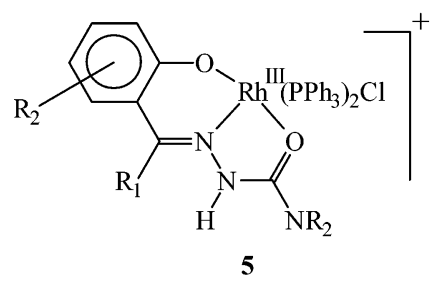

carbon then takes place, which is followed by other steps as shown before in Scheme 1. As all the $\left[\mathrm{Rh}\left(\mathrm{PPh}_{3}\right)_{2}\left(\mathrm{ONO}^{n}\right.\right.$ $\mathrm{NR}_{2}$ )Cl] complexes have been synthesized similarly and they show similar properties (vide infra), the other $\left[\mathrm{Rh}\left(\mathrm{PPh}_{3}\right)_{2}-\right.$ $\left(\mathrm{ONO}^{n}-\mathrm{NR}_{2}\right) \mathrm{Cl}$ ] complexes are assumed to have similar structure as $\left[\mathrm{Rh}\left(\mathrm{PPh}_{3}\right)_{2}\left(\mathrm{ONO}^{2}-\mathrm{NEt}_{2}\right) \mathrm{Cl}\right]$.

The microanalytical data of these $\left[\mathrm{Rh}\left(\mathrm{PPh}_{3}\right)_{2}\left(\mathrm{ONO}^{n}-\right.\right.$ $\left.\mathrm{NR}_{2}\right) \mathrm{Cl}$ ] complexes are in good agreement with their compositions (Table S1). ${ }^{1} \mathrm{H}$ NMR spectra of these complexes (Table 3) are also consistent with their compositions. In addition to broad signals for the triphenylphosphines $(7.0-7.8 \mathrm{ppm})$, some of the expected signals from the coordinated semicarbazones have been clearly located while others could not be observed due to their overlap with the triphenylphosphine signals. The signal for the azomethine proton is observed in the $\left[\mathrm{Rh}\left(\mathrm{PPh}_{3}\right)_{2}\left(\mathrm{ONO}^{1}-\mathrm{NR}_{2}\right) \mathrm{Cl}\right] \mathrm{com}$ plexes around $6.5 \mathrm{ppm}$, but the same could not be detected in the $\left[\mathrm{Rh}\left(\mathrm{PPh}_{3}\right)_{2}\left(\mathrm{ONO}^{3}-\mathrm{NR}_{2}\right) \mathrm{Cl}\right]$ complexes. In the $\left[\mathrm{Rh}\left(\mathrm{PPh}_{3}\right)_{2}\left(\mathrm{ONO}^{2}-\mathrm{NR}_{2}\right) \mathrm{Cl}\right]$ complexes, a distinct methyl signal is observed near $1.8 \mathrm{ppm}$. Signals for the $\mathrm{NR}_{2}$ fragment were observed in all these complexes in the expected region as before.

Infrared spectra of the $\left[\mathrm{Rh}\left(\mathrm{PPh}_{3}\right)_{2}\left(\mathrm{ONO}^{n}-\mathrm{NR}_{2}\right) \mathrm{Cl}\right] \mathrm{com}$ plexes are mostly similar to those of the $\left[\mathrm{Rh}\left(\mathrm{PPh}_{3}\right)_{2}(\mathrm{CNO}-\right.$ $\left.\mathrm{NR}_{2}\right) \mathrm{Cl}$ ] complexes. Electronic spectra of these complexes, recorded in dichloromethane solution, show several intense absorptions in the visible and ultraviolet region (Table 4). The absorptions in the ultraviolet region are assignable to transitions within the ligand orbitals. To understand the origin of the absorptions in the visible region, EHMO calculations 


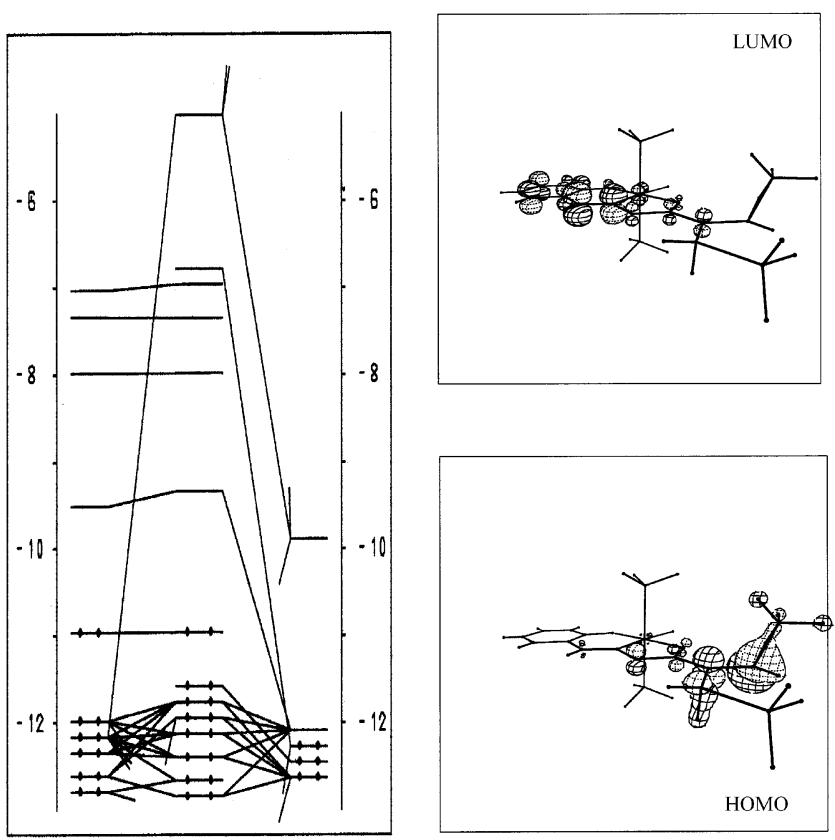

Figure 5. Partial molecular orbital diagram of $\left[\mathrm{Rh}\left(\mathrm{PPh}_{3}\right)_{2}\left(\mathrm{ONO}^{1}-\right.\right.$ $\left.\mathrm{NEt}_{2}\right) \mathrm{Cl}$.

have been performed on these complexes, which have afforded qualitatively similar results for all the complexes. The composition of some selected molecular orbitals of three representative complexes is given in Table 5, and a partial MO diagram for one complex is shown in Figure 5. The $\mathrm{HOMO}$ is primarily concentrated on the $\mathrm{NR}_{2}$ fragment of the semicarbazone ligand, while the HOMO -1 and HOMO -2 have significant $(42-83 \%)$ contributions from the metal d-orbitals. The LUMO is delocalized over the arylimine fragment, and the next few vacant orbitals (LUMO +1 , LUMO +2 , etc.) are localized on different parts of the semicarbazone ligand. The lowest energy absorption in the visible region may therefore be attributed to a transition from the HOMO concentrated on one part of the semicarbazone ligand to the LUMO localized on another part of the same ligand. The higher energy absorptions in the visible region may be assigned to transitions from the lower filled orbitals to the higher vacant orbitals.
The cyclic voltammetric behavior of the $\left[\mathrm{Rh}\left(\mathrm{PPh}_{3}\right)_{2^{-}}\right.$ $\left.\left(\mathrm{ONO}^{n}-\mathrm{NR}_{2}\right) \mathrm{Cl}\right]$ complexes, studied in 1:9 dichloromethaneacetonitrile (0.1 M TBAP) solution, is qualitatively similar to that of the $\left[\mathrm{Rh}\left(\mathrm{PPh}_{3}\right)_{2}\left(\mathrm{CNO}-\mathrm{NR}_{2}\right) \mathrm{Cl}\right]$ complexes. Each $\left[\mathrm{Rh}\left(\mathrm{PPh}_{3}\right)_{2}\left(\mathrm{ONO}^{n}-\mathrm{NR}_{2}\right) \mathrm{Cl}\right]$ complex shows one reversible oxidative response on the positive side of SCE and one irreversible reductive response on the negative side (Table 4, Figure 3), and in view of the results of the EHMO calculations, both the responses are assigned to ligand(semicarbazone)-centered redox reactions.

\section{Conclusions}

The present study reveals that reactivity of semicarbazone ligands gets modified considerably upon its coordination to an electropositive metal center and the coordinated semicarbazone ligand undergoes unusual chemical transformation via initial attack of nucleophiles to the carbonyl carbon. This study also shows that ligands of this type are likely to display interesting metal mediated chemical transformations upon reaction with nucleophiles of different types, and such possibilities are currently under exploration.

Acknowledgment. Financial assistance received from the Council of Scientific and Industrial Research, New Delhi [Grant 01(1675)/00/EMR-II], is gratefully acknowledged. The authors thank Professor B. C. Ranu and Professor S. Lahiri of the Department of Organic Chemistry, Indian Association for the Cultivation of Science, Kolkata, for their help. Thanks are also due to the RSIC at Central Drug Research Institute, Lucknow, India, for the $\mathrm{C}, \mathrm{H}, \mathrm{N}$ analysis data and the Bose Institute, Kolkata 700054, for NMR spectral measurements. The authors thank the reviewers for their critical comments and constructive suggestions, which have been helpful in preparing the revised version.

Supporting Information Available: Table containing microanalytical data of the $\left[\mathrm{Rh}\left(\mathrm{PPh}_{3}\right)_{2}\left(\mathrm{CNO}-\mathrm{NR}_{2}\right) \mathrm{Cl}\right]$ and $\left[\mathrm{Rh}\left(\mathrm{PPh}_{3}\right)_{2-}\right.$ $\left(\mathrm{ONO}^{n}-\mathrm{NR}_{2}\right) \mathrm{Cl}$ ] complexes (Table $\left.\mathrm{S} 1\right)$. X-ray crystallographic data in CIF format. This material is available free of charge via the Internet at http://pubs.acs.org.

IC034247J 